\title{
Transformation of Legal Education in Indonesia Based on Social Justice
}

\author{
Otong Rosadi ${ }^{1} \&$ Awaludin Marwan ${ }^{2}$ \\ ${ }^{1}$ Faculty of Law, Universitas Ekasakti, Padang, Indonesia \\ ${ }^{2}$ Faculty of Law, Universitas Bhayangkara, Jakarta, Indonesia \\ Correspondence: Awaludin Marwan, Faculty of Law, Universitas Bhayangkara, Jakarta, Indonesia. E-mail: \\ luluk_hukum@yahoo.co.id
}

Received: January 8, 2020

doi:10.5539/jpl.v13n1p143
Accepted: February 6, 2020

Online Published: February 29, 2020

URL: https://doi.org/10.5539/jpl.v13n1p143

\begin{abstract}
The transformation of legal education in Indonesia has become the study and anxiety of many legal experts in Indonesia. Legal education is seen as only producing law graduates who are no more legal craftsmen. Legal education ignores the ideologization of social justice values. Therefore, the transformation of higher legal education in Indonesia absolutely must be done by first carrying out an inventory of the main problems in the legal education system in Indonesia. This article attempts to perform an analysis of the description of the main problems in the legal education system and the steps that should be taken to hasten the transformation of higher legal education in Indonesia. Changes in the Legal Studies Curriculum and the transformation of the learning process that is more oriented towards humanizing lecturers and students have become an urgent need. One of the short-term offers is to make Legal Clinical Education as a compulsory subject in the Legal Studies Program. Whereas the other offer is transformation the Legal Studies Curriculum, Legal Learning Methods and Processes that are oriented in mastering the legal knowledge, legal skills, and law students' alignments on issues of law and justice.
\end{abstract}

Keywords: transformation in higher education, clinical legal education, social justice

\section{Introduction}

Nowadays, the chaotic state of governance of this country, corrupt behavior, vigilantism, and various bad behaviors of this nation, are imposed on universities. Higher education seems to be the accused institution for several problems in our society. Higher education is considered the institution that fails to educate this nation's elites specifically and citizens of this nation in general. The most seizing public attention from many of the problems that occur is legal issues. In Indonesia - since the Reformation on "the legal state conception, legal politic, legal enforcement, and of course higher legal education", continues to be the relentless discourses and this even becomes daily fray. This excitement is not only about its law, but also the response to the excitement of the law can come from anyone. Even from one or two 'flirty' legal observers commenting outside their expertise, thus it makes fellow legal observers, academics, and practitioners become hostile and endlessly frenetic.

This study, not only responds to the request of the Universitas Lampung's, Law Faculty of National Seminar Committee entitled "Pancasila-Based Legal Education as Legal Development Efforts in Indonesia" (Dec, 2nd, 2019), but also the response to the importance of Social Justice with the Basis of Legal Education Reform, as the basic principle of legal development in Indonesia based on Pancasila. In other words, the writer wants to offer how to formulate Social Justice Based Education as the Foundation for Legal Development Based on Pancasila?

\section{The Reason for Need of Legal Education Transformation}

The International Symposium on Clinical Legal Education at Universitas Islam Indonesia on 20-23 September 2011 concluded that legal education ignores social justice. This condition is seen from legal education institutions that only produce alumni who have professional competency qualifications in the legal field. Higher legal education (Legal Faculty and Higher Legal School) is oriented towards the achievement of alumni mastering or competence in legal knowledge and skills. Legal education is more concerned with the making of legal craftsmen and professional legal experts while ignoring the ideology of social justice. The main problem in national law concerns the problem of social injustice for the community. This problem is not much formulated in 
legal education (curriculum). The International Symposium concludes that the law study program has not yet made social justice the mainstream of legal education needs to revolutionize its curriculum, therefore legal clinical education is one of the solutions that must be included in the preparation of the Law curriculum.

In line with the results of this symposium, from the writer's perspective, there are at least three main issues in higher legal education: First, the failure of legal education in Indonesia to idealize the values of social justice in legal education so far. Second, the stuttering of legal education educators in Indonesia responds to internal challenges in Indonesian Legal Studies. Third, the unpreparedness of higher legal education responds to external challenges. The development and legal needs of a society that continues to develop rapidly.

Evidence of the failure from legal education in Indonesia to idealize the values of social justice can be seen from the few alumni of the Faculty of Law who are present in the middle and together with the community, at a time when the people seeking justice need their presence. The issue of social injustice is a major problem in this republic. The issue which is 'the main cause (causa prima)' of Indonesia's need to be independent, but it has always been an agenda that can never be solved or reduced. And the Legal Faculty and other legal education institutions failed to make efforts to instill the values of social justice into internalized values in the contents of the curriculum of higher legal education. Therefore, higher legal education also failed to provide legal graduates with whom appear alignments with the values of social justice.

Another issue that with similar importance is the failure of legal education in Indonesia to answer key questions about the place and position of legal science within the legal framework and characteristics of Indonesian legal studies. This becomes very important because failing to understand this thing becomes one of the main reasons for the failure to internalize or rather idealize the values of justice in the Indonesian legal education curriculum.

Transformation of higher legal education in Indonesia is urgently needed because there are two external challenges which require the society to 'wake up', namely legal education curriculum is indeed acknowledged to be unable to answer the challenge of the times, which has implications for the availability of professionals in the legal field become very limited. While abroad, the clear challenge before our eyes is the implementation of free trade in Southeast Asian Countries (ASEAN) in 2015 through the ASEAN Economic Community and AFTA-WTO 2020.

This article, after carrying out the inventory of the main problems in the legal education system in Indonesia, it will try to offer a re-establishment on the kind of Indonesian Legal Education Consortium, which will carry out the inventory, analyze, and recommend measures for the transformation of higher legal education in Indonesia. So after analyzing the main problems in the legal education system and the steps should be taken to accelerate the transformation of higher legal education in Indonesia.

\section{Legal Education at the Crossroad}

The transformation of legal education in Indonesia has been studied by many legal professors in Indonesia. The prominent most figures are Prof. Mochtar Kusumaatmadja, Prof. Satjipto Rahardjo, and Prof. Sunaryati Hartono. The National Legal Development Board has specifically made the Legal Education Reform as a special study, in the National Legal Seminar. This is possible because legal educators in Indonesia see that the Legal Education Curriculum must be immediately adapted to the development needs of the community on one hand and the development of the character of Indonesian Legal Studies on the other hand.

The 1970s were seen as the 'golden year' in the development (read: transformation) of legal science education in Indonesia. Because for decades, legal education in Indonesia is only focused on statutory law (alles Binnen het Recht). At that moment, the study has begun on social and sociological toward the law and the establishment of Legal Studies centers in the social context. ${ }^{1}$

Professor Mochtar Kusumatmadja is a professor who is very interested in Legal Education in Indonesia. He wrote a working paper "Problems of Legal Education in Indonesia: Challenge and Response" at the Lawasia Conference in Manila in 1970. Then the paper "Transformation of Education and Professional Development", as a working paper presented at the Symposium "Transformation of Legal Education and Coaching Profession "in Lembang, West Java in 1975. Professor Mochtar departed from the idea that the challenges of legal graduates in the colonies with those in an independent country were very different. There are differences in position and

\footnotetext{
${ }^{1}$ Satjipto Rahardjo, Ilmu Hukum di Indonesia Dalam Lintasan Perkembangan Sains, in Esmi Warassih, Suteki, and Awaluddin Marwan, Refleksi dan Rekonstruksi Ilmu Hukum Indonesia, Yogyakarta: Thafa Media, 2012, page. 627. The awareness to transform legal education had begun in the late 1950s. Then in the conference between Legal Faculties in 1962, the idea of renewal was also conveyed. Look in Khudzaifah Dimyati, Teorisasi Hukum: Studi tentang Perkembangan Pemikiran Hukum di Indonesia 1945-1990, Surakarta: Muhammadiyah University Press, 2004, page. 207.
} 
responsibility (role). Such differences naturally also result in the difference in the legal education curriculum that must be presented in its Legal Education. Another factor that is not less important can be seen from the difference in his perspective on the function of law in society, which he began to develop as Legal Theory as a Means of Development which is a modification and adaptation of the Roscoe Pound Theory to the Indonesian situation. $^{2}$ According to Mochtar Kusumaatmadja, the transformation of legal education is carried out by changing one's attitude toward problems and the need for legal professional skills training. This is done as the balance of the current legal education that tends to be scientific theoretical and pretend 'academic university'. ${ }^{3}$

In the period of Legal Studies Consortium and the Disciplinary Commission of Legal Sciences - the era of Prof Satjipto Rahardjo, Prof. JE Sahetapy, Prof. Mochtar Kusumaatmadja, and Prof Mardjono Reksodiputro-legal education development cooperation in Indonesia continue to be encouraged, even with the United States. Many Indonesian students receive scholarships through the ELIPS (Economic Law and Improved Procurement System) program. One of the think tanks for developing legal education in the United States in the 1970s was the International Legal Center (ILC), where Mochtar is listed as an administrator. One of the 'legacies' of ILC in Indonesia is clinical legal education. In a report entitled Legal Education in a Changing Word, ILC concluded that more needs to be done to help develop legal science in developing countries, including Indonesia. 'In our report, we have also identified some topics which may be particularly important for the planning of development of legal education '.

According to Prof. Dr. Satjipto Rahardjo, SH, since the establishment of modern law, the legal journey has faced a deviation (bifurcation), between realizing justice and applying the law (professionalism) ${ }^{5}$. In the meantime, Professor Satjipto Rahardjo, criticizing legal education in Indonesia that only produces legal craftsmen. In his Professor Inaugural Speech, he mentioned:

$" . .$. that our legal education does not educate them to really and systematically study the law as a regulatory tool in society, but only about how to properly implement the law. In short, it can be said that the skills taught are craftsmanship skills. ${ }^{6}$

Unlike the view of Professor Satjipto Rahardjo, Professor Sri Redjeki Hartono said that the main task of education is to prepare students for life in the future, mostly to get such broad jobs in society. Thus, legal education is a place to prepare students to become professional legal actors. ${ }^{7}$ This same view was also confirmed by Professor Barda Nawawi Arief who stated that the policy of higher legal education in the S-1 program outlined by the Consortium of Legal Sciences was "Expertise and professional skills as legal graduates."

In the writer's view, the Curriculum and Teaching Methods for Legal Education in Indonesia are at the crossroads. Besides being burdened by 'innate problems' in the form of orientation and practice of legal education in Indonesia which emphasizes more on the development of (professional) skills based on legal knowledge and the practice of the use of the law. This results in the neglect of aspects of humanity and human, become less attention and pushed aside. Also because of the leap in the development of technological science and the development of the international society that continues to move quickly. These internal and external challenges require Legal Education in Indonesia to immediately transform Indonesian Legal Education. Also, of course, an equally important problem is 'failure to understand' (doubt and even incomprehension) from Legal Teachers in Indonesia regarding the place and task of Legal Studies in Indonesia today.

The structuring of legal education in Indonesia is very urgent because the economic globalization (even the world) requires that the Indonesian legal system interfere directly with the legal systems of other countries which will affect the Indonesian legal system based on Pancasila and the 1945 Constitution. Denial of this condition is impossible to be done, therefore Legal Education, as part of the national legal subsystem, must be ready to be an inseparable part of the world life which is constantly moving, constantly changing. For this matter, Prof. Khudzaifah Dimyati offers a change in the paradigm of legal education, by starting to fundamentally change education as a dynamic subject of the reality of people's lives so that understanding of law becomes holistic,

\footnotetext{
${ }^{2}$ Mochtar Kusumaatmadja, Hukum, Masyarakat dan Pembinaan Hukum Nasional, Bandung. The Legal and Criminology Research Institute of the Faculty of Law Universitas Padjadjaran, 1976, page. 24-25.

${ }^{3} \mathrm{Ibid}$, home. 26. Professional education is not only professional skills but also professional ethics and professional responsibility.

${ }^{4}$ http://www.hukumonline.com/berita/baca/lt51a71729d07f5/bermula-dari-irechtshogeschool-i

${ }^{5}$ Satjipto Rahardjo, Hukum dan Perilaku, Jakarta, Kompas, 2009, pages. 97-100.

${ }^{6}$ Khudzaifah Dimyati, op. cit., page. 211.

${ }^{7}$ Ibid, page 213.
} 
visionary, and meaningful. ${ }^{8}$

\section{Globalization and Transformation of Higher Law Education}

Globalization requires that the Indonesian legal system directly intersects with the legal systems of other countries which will affect the Indonesian legal system based on Pancasila and the 1945 Constitution. Disavowal of this condition is not possible, therefore Legal Education, as part of the national legal subsystem, must be ready to become a part of inseparable from the life of a world that is constantly moving, constantly changing.

About Globalization, we need to consider some conclusions from the legal Seminar on "Marrakech Agreement and Its Implications for National Law", that in building an adequate national legal system to strengthen Indonesia's position in the international market, there are 7 (seven) aspects that must be considered, that is:

1) aspects of lawmaking

2) aspects of the application of law and legal services

3) aspects of dispute resolution, both through the courts and through alternative dispute resolutions.

4) human resource development and professional specialization in the field of law, including the modernization of the legal education system (formal, non-formal, and informal)

5) increasing the collection of legal information and the effectiveness of disseminating legal information through a legal information network system

6) research the legal language used in international agreements, specifically the WTO agreement and the standardization of legal language through comparison of legal languages internationally and nationally, and

7) the development of methods of legal interpretation, especially the legal interpretation of the clauses of the WTO agreement. ${ }^{9}$

The seven aspects above reiterate the necessity or urgency of Legal Education in Indonesia to immediately undertake the Transformation of Indonesian Legal Education. In the writer's view, a solution that can be done immediately is to re-establish the Legal Studies Consortium (Study Program), which takes the following steps: First, compiling a ledger to reorient Indonesian legal education; Secondly, it emphasizes that legal education is part of the development of a national legal system based on the National Philosophy. Third, Legal Education in Indonesia must make lecturers and students the center of learning, and Fourth, organizing competency-based learning processes based on an understanding of learning to know, learning to do, learning to live together, and learning to be from the Legal Studies Program. These five things must be formulated together with the Competency Qualification Standards for Legal Education Graduates in Indonesia.

In the Jentera Journal Special Edition on Legal Education, October $2013^{10}$, mentioned that the first and most important basic ability is the ability to think critically analytically. It should be underlined that studying law is not memorizing articles, but how to form a critical frame of mind so that it can analyze legal issues well. This ability which then impacts on other basic abilities that need to be had. A law scholar is expected to understand the principles, principles and legal provisions he studies to understand the background and logic behind why this is regulated? The basic ability that must be possessed is to be able to translate everyday concepts or legal concepts into legal products. Then those who undergo the legal profession must have the same service delivery standards. These capabilities should have the same national standards, and also in the same system. So that the legal profession can only be followed by selected people who have proven their insights, skills, and integrity. Because, how can enforce the law governing all aspects of human life if law enforcement officials do not have the insight, ability, and integrity of the good self.

In another part of the article in the Lantern Journal, it is mentioned ${ }^{11}$ that if we focus on the US system, it is rather complicated. Because legal education there is equivalent to the S-2 level. Many parties will be disadvantaged from the current conditions. And when oriented to the public system that is a mere academic, law schools will be 'sublime (read: high)' ivory tower, but was unable to do anything in practice. While the demands of society require a law degree that is ready to use. What the law school has to do now is to organize academic and professional legal education as well. This is not new considering that several law faculties currently have a

\footnotetext{
${ }^{8}$ Ibid, page. 219.

9 M. Hudi Asrori S., Peranan Hukum di Dalam Menghadapi Transformasi Global di Bidang Ekonomi, http://eprints.uns.ac.id/1955/1/45-fullteks.pdf

${ }^{10} \mathrm{http}: / /$ asep.wordpress.com/2004/12/01/pendidikan-hukum-di-indonesia-perlu-jalan-alternatif/

${ }^{11} \mathrm{http} / / /$ asep.wordpress.com/2004/12/01/pendidikan-hukum-di-indonesia-perlu-jalan-alternatif/
} 
professional legal education, although it is limited to the notary field.

But the consequence of this choice is that the study time will take longer. At least it will be similar to the faculty of medicine. Where graduates who have completed the S-1 program are entitled to hold a bachelor's degree but are not yet allowed to practice. For this reason, he will retake further education which provides him with practical skills. Agree with the study in the Jentera Journal above, that students of the Legal Faculty no longer have to be bothered with memorizing article by article, nor do they have to know the number of articles in each Law Book (wetboek) or a Legislation, Contract or Treaty. They need to have the one basic capability provided in the form of a desire to continue learning and scientific thinking, analyzing, logic, were able to convey the idea (rhetorics), and most importantly, the spirit of seeking the truth. ${ }^{12}$

About Legal Education in the Era of Globalization, the view of Professor Erman Rajagukguk in his Inaugural Speech concluded that:

"The Legal Faculty in the era of globalization must prepare its students with sufficient education. On one hand, legal education produces legal graduates who have skills in legal practice that contain international elements; on the other hand equip them with the ability to deal with various problems facing society, including providing legal assistance to those most affected by the globalization process." ${ }^{13}$

\section{Legal Clinic Education and Consortium of Legal Studies: An Offer}

Regarding Legal Education with the basis of Social Justice, Jimmy Asshiddiqie ${ }^{14}$ argues that the perspective about social justice is very important in the life of society, nation, and state. Although Social Justice is the fifth precept of Pancasila, in reality, no one realizes the importance of realizing social justice. Many people do not care or understand the nature of social justice in life. Therefore, awareness-raising efforts are needed and are specifically linked to the education agenda in general and especially higher education. Especially for those of us who serve in the world of higher legal education, what we need to think about is how to do the "mainstreaming" of awareness, understanding, appreciation, and practice of the principles of social justice in legal faculties throughout Indonesia. These constitutional messages about social justice must penetrate our higher legal education system in Indonesia. Of course, we must also understand that in the education system we are also faced with things, namely (i) education as content, (ii) education that is competent based, and (iii) education as a process.

The efforts to mainstream social justice values can be seen as curriculum issues. What people usually think about is how to add new subjects or new teaching material in the education curriculum. The "content base" approach in the curriculum is considered outdated by education experts. Therefore, instead of many education experts encourage new perspectives, namely "competent base curriculum", no longer a "content-based curriculum". The important thing is not the learning contents, but the future of graduate education so we need to prepare them with the knowledge, skills, and attitudes relevant. But in addition to the two approaches, the third perspective is important but often forgotten today, namely education as a process. Education of social justice should be seen as a process where learners should be allowed to hang out and experience for themselves the various issues of social injustice which need to be tackled and overcome, so that social justice embodied in the reality of life in a society, nation and state. ${ }^{15}$

One offer through the transformation of legal education in Clinical Legal Education. Clinical Legal Education (PHK) equips students with practical legal knowledge, skills, and values, to realize the legal service and social justice. ${ }^{16}$ The following are some examples of curriculums that have been implemented at tertiary institutions in Indonesia.

Legal Faculty at Universitas Padjadjaran ${ }^{17}$ have introduced the Law Clinic Education as a part of elective courses for students of semesters 5 and above who have taken prerequisite courses. Legal Clinic Education courses provide opportunities for students to have practical experience in the legal world. Legal Clinic Education was re-activated in October 2012 through the training of Civil Law Clinic and Criminal Law Clinic which was

\footnotetext{
12 http://asep.wordpress.com/2004/12/01/pendidikan-hukum-di-indonesia-perlu-jalan-alternatif/

${ }^{13}$ Erman Rajaguguk. "Peranan Hukum Dalam Pembangunan Pada Era Globalisasi: Implikasinya Bagel Pendidikan Hukum Di Indonesia" Inauguration speech was pronounced at the ceremony of accepting the position of Professor in the field of law at the Faculty of Law Universitas Indonesia, Jakarta, 4 January 1997

${ }^{14}$ http://www.jimly.com/makalah/namafile/75/PESAN_KEADILAN_SOSIAL.pdf

${ }^{15} \mathrm{http} / / /$ www.jimly.com/makalah/namafile/75/PESAN_KEADILAN_SOSIAL.pdf

${ }^{16} \mathrm{http}: / /$ www.tifafoundation.org/paradigma-pendidikan-hukum-mesti-berubah/

${ }^{17}$ http://fh.unpad.ac.id/pkh/
} 
carried out in collaboration with the Legal Faculty at Universitas Padjadjaran and The Asia Foundation through the Educating and Equipping Tomorrow's Justice Reformers program (E2J). This training is offered to students of the Legal Faculty at Universitas Padjadjaran who have taken courses in Criminal Procedure, Criminal Legal Proficiency, Civil Legal Procedure, and Civil Legal Proficiency.

In the even semester of 2012-2013, the Civil Legal Clinical Education and Anti-Corruption Clinics courses officially became the elective courses at the Faculty of Law at Universitas Padjadjaran. This course weighs 2 credits, with a calculation of 1 credit $=3-4$ hours so it is done $2 \mathrm{x} 1$ week. Therefore, participants who will take this course are specifically selected. The Purpose of Legal Clinic Education: (1) Preparing graduates who are ready to implement legal science in the community. (2) Providing experience to students to work in the legal field. And (3) Providing experience to students to go directly to the community. ${ }^{18}$

The Benefits of Clinical Legal Education: 1. Students are ready to implement legal knowledge in the community, 2. Having experience with students to work in the field of law, 3. Having experience for students to go directly to the community, 4. Teachers from academia and practitioners, 5. Students are accompanied intensively by the instructors. 6. Opportunity to do community service. ${ }^{19}$

At the Legal Faculty of Padjadjaran University, the lecture teaching method is divided into three stages, namely planning; experiential (field practice) and reflection (evaluation of the implementation of activities): First, the planning stage generally contains refreshment of the basic material that has been learned and techniques to be applied at the field of practical practice (experiential). In the planning stage, lectures will take place in the Legal Clinic Building, 3rd Floor Progo St. No. 17 Bandung 40115. Second, meanwhile the stage of the field practice (experiential), the students were accompanied by a partner institution of FH Unpad to go directly to the community. Stage of field practice (experiential) students carry out activities in the teaching office of the practitioners or directly to the field (courts, mediation, consultation, negotiation, research, advocacy, outreach). The final third stage, namely evaluation (reflection), is a report and feedback from students for the implementation of this curriculum. ${ }^{20}$ However, it is still unfortunate that the Legal education Clinic at the Legal Faculty in Universitas Padjadjaran still is a part of elective courses for students of semesters 5 and above who have taken certain prerequisite courses. So it is not a compulsory subject yet.

Likewise with the Legal Faculty, Universitas Gadjah $\mathrm{Mada}^{21}$ have also begun to develop clinical legal education as a teaching program based on interactive and reflective methods. Clinical legal education contains knowledge, values, and practical expertise that makes students able to provide legal services and create social justice. The clinical legal education method is a breakthrough needed to ensure that every law graduate will have skills in applying legal knowledge by the legal problems faced by the community by the references in the Indonesian National Qualification Framework (KKNI).

The Legal Faculty of Universitas Indonesia introduced a legal clinic as a course in its curriculum. At FH-UI, four legal clinics are running, namely criminal clinics, civil clinics, women's and children's legal clinics, and anti-corruption clinics. FH-UI Legal Clinic Course is organized by the Laboratory Unit, Law Clinic and FH-UI Student Competition. Student recruitment for Legal Clinic Courses is conducted at least two months before the start of the new semester. The recruitment consisted of three stages, namely the administration phase, the written test stage, and the interview stage. By following this lecture, students are expected to have mastered the law both formally and materially (applicatively) applied in the field. Students are also expected to get to know legal practices in the field with an experience that is directly given. Also, students are directed to be sensitive to the constraints of law enforcement in Indonesia. In the end, students are expected to be skilled in conducting legal analysis and can provide appropriate solutions to the legal problems they face.

The method of implementing the Law Clinic lectures at FH-UI is carried out in three ways. First, in the form of face-to-face meetings (30\%). In face-to-face meetings, students are provided with a brief review of the legal clinic, implementation procedures, objectives, evaluation system, explanation and distribution of lecture materials, explanation of Indonesian law, and provision of insight into legal practice in Indonesia. Also, students are given technical supplies, such as interview techniques, case analysis techniques (criminal law clinics), negotiation techniques, and techniques for making legal documents (civil law clinics). Second, practice (in house and/or ex-house) (65\%). In practice, the legal clinic works closely with several institutions, to place students who

\footnotetext{
${ }^{18} \mathrm{http}: / /$ fh.unpad.ac.id/pkh/

${ }^{19}$ http://fh.unpad.ac.id/pkh/

${ }^{20}$ http://fh.unpad.ac.id/pkh/

${ }^{21} \mathrm{http}: / /$ edukasi.kompas.com/read/2011/09/21/10051610/Fakultas.Hukum.UGM.Kembangkan.Pendidikan.Hukum
} 
take part in this course. In this practical meeting also included a reflective meeting intended to monitor students in carrying out the practice. Third, the latest is evaluation (5\%). At the end of the semester, students will be evaluated by law clinic lecturers in theory and practice related to lectures for one semester. The method used in carrying out the evaluation is in the form of daily activity notes in the form of pocketbooks, field observations, case study reports, and final semester examinations in the form of presentation of activity results.

Another offer is to include the substances of each course material that contains the values of social justice in each course offered in the Legal Studies curriculum. The learning process must be oriented to mastering the competencies of graduates, someday graduating from education later so that we need to prepare them with relevant knowledge, skills, and attitudes.

It is also important for students to be allowed to get along and experience various social injustice issues that need to be addressed and overcome. The point is how the Legal Studies Curriculum, Legal Learning Methods, and Processes are oriented not solely to the mastery of legal science, the mastery of legal skills, also to the alignment of legal students on legal and justice issues in their society.

\section{Conclusion}

Amid the chaotic education system in Indonesia, which is characterized by law enforcement efforts that move away from the sense of justice of society in Indonesia today. Then higher legal education in Indonesia needs to be reoriented. Transformation Legal Education in Indonesia must be done by preparing students in the faculty of law by understanding legal knowledge, mastering legal skills, and internalizing values and attitudes in favor of community justice. Thus, the Transformation of Legal Education must include: Legal Studies Curriculum, Legal Learning Methods, and Processes oriented not solely to the mastery of legal knowledge, mastery of legal skills, also to the alignment of law students on legal and justice issues in their communities.

One of the offers for legal education renewal in Indonesia, which is short-term, and can be done immediately by the Legal Faculty is to include clinical legal education. This clinical legal education contains or includes legal knowledge, practical expertise, and values that make students able to provide legal services and endeavor to bring social justice in the community.

Transformation legal education is not only the responsibility of the Legal Faculty but is the responsibility of the entire legal community, such as judges, prosecutors, lawyers and parties related to the legal world. From the university must be started, the entire Legal Study Program must encourage the rebirth of institutions such as the Legal Studies Consortium, which must be held to prepare a Comprehensive Reorienting of Higher legal Education in Indonesia. Other legal communities play an active role, legal practitioners participate in teaching S1 Law and Advanced Program programs (Professional and Masters Programs). Also, practitioners (users) make a selection to screen law faculty graduates to become practitioners in one system nationally. Of course, it must be free from $\mathrm{KKN}$ to be able to produce legal practitioners who are not only skilled and broad-minded but also with integrity.

\section{References}

Dillabough, J.-A. (2008). Degrees of Freedom and Deliberations of Self The Gendring of Identity in Teaching Larry. Cata Backer. Internationalizing the American Law School Curriulum (in Light of the Carnegic Foundation's Report. Jan Klabbers\&Mortimer. The Internationalization of Law and Legal Edducation.

Dimyati, K. (2004). Teorisasi Hukum: Studi tentang Perkembangan Pemikiran Hukum di Indonesia 1945-1990. Muhammadiyah University Press, Surakarta.

Freire, P. (2005). Pedagogy of the Oppressed. Continuum. New York \& London.

http://asep.wordpress.com/2004/12/01/pendidikan-hukum-di-indonesia-perlu-jalan-alternatif/

http://edukasi.kompas.com/read/2011/09/21/10051610/Fakultas.Hukum.UGM.Kembangkan.Pendidikan.Hukum. Klinis

http://eprints.uns.ac.id/1955/1/45-fullteks.pdf

http://fh.unpad.ac.id/pkh/

http://kampus.mitrahukum.org/?p=12

http://soetandyo.wordpress.com/2012/12/30/mochtar-kusumaatmadja-manusia-yang-pernah-saya-kenal-dan-pem ikirannya/

http://www.hukumonline.com/berita/baca/lt51a71729d07f5/bermula-dari-irechtshogeschool-i 
http://www.hukumonline.com/berita/baca/lt51a71729d07f5/bermula-dari-irechtshogeschool-i

http://www.jimly.com/makalah/namafile/75/PESAN_KEADILAN_SOSIAL.pdf

http://www.tifafoundation.org/paradigma-pendidikan-hukum-mesti-berubah/

Hudi, M., \& Asrori, S. (n.d.). Peranan Hukum di Dalam Menghadapi Transformasi Global adi Bidang Ekonomi. Retrieved from http://eprints.uns.ac.id/1955/1/45-fullteks.pdf

Kennedy, D. (2004). Legal Education and the Reproduction of Hirarkhy A Polemic Against The System. New York University Press.

Kusumaatmadja, M. (2002). Konsep-konsep Hukum dalam Pembangunan: Kumpulan Karya Tulis Prof. Dr. Mochtar Kusumaatmadja. SH. LLM. Alumni. Bandung

Manan, B. (2011). Pembaharuan Pendidikan Tinggi Hukum di Indonesia, Keynote Speech pada Diskusi Akademik 'Rekonstruksi Pemikiran Hukum di Indonesia, dalam rangka Purnabakti Prof. Dr. Bagir Manan,S.H.,M.CL, yang diselengagarkan oleh Fakultas Hukum Universitas Padjadjaran, Bandung.

Plana, R. M. (1997). Critical Thinking Inside Law Schools: An Outline. Onati-Socio-legal Series Richard Johnstone\&Gordon Joughin. Designing Print Materials for Flexible Teaching and Learning in Law. Cavendish Publishing. New South Wales.

Rahardjo, S. (1979). Hukum dan Perubahan Sosial. 1979, dicetak ulang pada 2009, Genta Pubslishing. Yogjakarta.

Rahardjo, S. (2009). Hukum dan Perilaku. Jakarta, Kompas.

Rajaguguk, E. (1997). "Peranan Hukum Dalam Pembangunan Pada Era Globalisasi : Implikasinya Bagl Pendidikan Hukum Di Indonesia" Pidato pengukuhan diucapkan pada upacara penerimaan jabatan Guru Besar dalam bidang hukum pada Fakultas Hukum Universitas Indonesia, Jakarta.

Rosadi, O. (2014). makalah Transformasi Pendidikan Tinggi di Indonesia: Telaah Atas Pembaharuan Pendidikan Hukum, Kertas Kerja untuk International Seminar on Global Education II di UKM Malaysia.

Rosadi, O. (n.d.). Critical Contemplation High Education in Indonesia: Law School Struggle. Journal Social Science Research Network. Retrieved from http://papers.ssrn.com/sol3/papers.cfm?abstract_id=2208503

Scholten, P. (n.d.). Struktur Ilmu Hukum, (Alih Bahasa: B. Arief Sidharta). Alumni, Bandung.

Sidharta, B. A. (2009). Refleksi Tentang Struktur Ilmu Hukum: Sebuah Penelitian Tentang Fundasi Kefilsafatan dan Sifat Keilmuan Ilmu Hukum Sebagai Landasan Pengembangan Ilmu Hukum Nasional Indonesia, Mandar Maju, Bandung.

Walshaw, M. (2007). Working with Foucault in Education. Sense Publishers. https://doi.org/10.1163/9789087903145

Warassih, E. (2012). Suteki dan Awaluddin Marwan, Refleksi dan Rekonstruksi Ilmu Hukum Indonesia. Yogyakarta: Thafa Media.

Wignjosoebroto, S. (n.d.). Mochtar Kusumaatmadja: Manusia Yang Pernah Saya Kenal Dan Pemikirannya. Retrieved from http://soetandyo.wordpress.com/2012/12/30/mochtar-kusumaatmadja-manusia-yang-pernah-saya-kenal-dan -pemikirannya/

\section{Copyrights}

Copyright for this article is retained by the author(s), with first publication rights granted to the journal.

This is an open-access article distributed under the terms and conditions of the Creative Commons Attribution license (http://creativecommons.org/licenses/by/4.0/). 